\title{
Regional-scale extremes in river discharge and localised spawning stock abundance influence recruitment dynamics of a threatened freshwater fish
}

Zeb Tonkin ${ }^{1,2 *}$, Joanne Kearns ${ }^{1}$, Jarod Lyon ${ }^{1}$, Stephen Balcombe ${ }^{2}$, Alison King ${ }^{3}$, Nick Bond ${ }^{4}$

${ }^{1}$ Arthur Rylah Institute for Environmental Research, Department of Environment, Land Water and Planning, Heidelberg, Victoria, 3084, Australia.

${ }^{2}$ Australian Rivers Institute, Griffith University, Nathan, Qld 4111, Australia.

${ }^{3}$ Research Institute for Environment and Livelihoods, Charles Darwin University, Darwin, NT, Australia

${ }^{4}$ Murray-Darling Freshwater Research Centre, La Trobe University, Wodonga, VIC 3689, Australia

*Corresponding author:

Zeb Tonkin

Applied Aquatic Ecology,

Arthur Rylah Institute for Environmental Research,

Department of Environment, Land, Water and Planning

Post Office Box 137,

Heidelberg, Victoria, 3084, Australia.

Tel: +61394508660

Email: Zeb.Tonkin@delwp.vic.gov.au

This is the author manuscript accepted for publication and has undergone full peer review but has not been through the copyediting, typesetting, pagination and proofreading process, which may lead to differences between this version and the Version of Record. Please cite this article as doi: $10.1002 /$ eco.1842

This article is protected by copyright. All rights reserved. 
Key words: Endangered species; Spatial synchrony; Macquarie perch; Disturbance events;

\section{Conservation}

Running head: Recruitment dynamics of a threatened freshwater fish

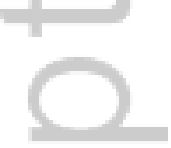

This paper has not been submitted elsewhere in identical or similar form, nor will it be during the first three months after its submission to Ecohydrology

This article is protected by copyright. All rights reserved. 


\section{Abstract}

Highly variable recruitment is common for many riverine fish species, governed by a wide range of biotic and abiotic drivers that operate at local and regional scales. The dynamics and drivers of recruitment for many Australian freshwater fish species, particularly those that are rare and long-lived, are relatively undescribed. This study describes the recruitment dynamics of an endangered riverine fish, Macquarie perch Macquaria australasica, across five isolated populations from south-eastern Australia, and relates these dynamics to drivers that vary at local and regional scales. We hypothesised large flow events occurring during the core egg and larval period would be negatively associated with recruitment strength and that recruitment patterns across populations would fluctuate in synchrony in response to extremes in river discharge resulting from regional-scale climatic patterns.

Discharge during the core egg and larval period, which was highly correlated across the region; and a local scale variable, spawning stock abundance, were the covariates most important in explaining recruitment strength. We also observed synchronised patterns in recruitment across our populations, thus conforming to predictions of the Moran effect (environmental synchrony). The findings suggest most remnant populations of Macquarie perch, which are now predominantly isolated within small tributary systems characterised by highly variable flows, face a heightened risk of poor recruitment periods, particularly under climate change predictions. The synchronised patterns in recruitment suggests threatened freshwater fishes like Macquarie perch with highly fragmented isolated

This article is protected by copyright. All rights reserved. 
populations, have an increased risk of the regional population becoming imperilled, thus, the need for a coordinated multijurisdictional conservation approach.

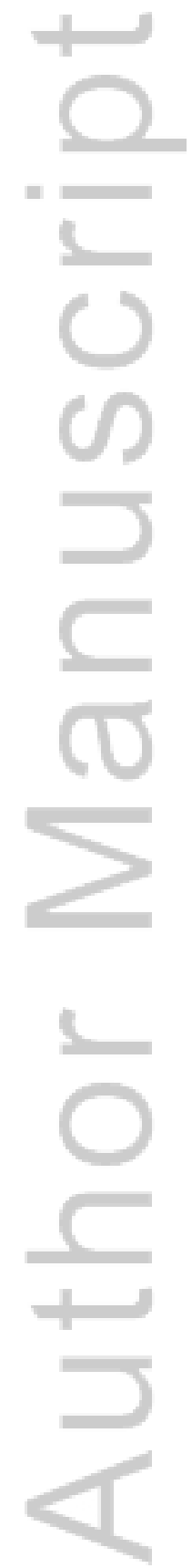

This article is protected by copyright. All rights reserved. 


\section{Introduction}

Environmental variability is a major driver of animal population dynamics (Ginzburg 1986). For fish in riverine environments, large-scale disturbances such as floods and droughts, can have major influences on populations by altering their size- and age-structure and abundance (Labbe and Fausch 2000; Milner et al., 2003; Arthington and Balcombe 2011). Effective conservation and management of fish populations requires an understanding of how such environmental variability influences basic demographic processes such as recruitment, mortality and migration. Recruitment, defined as the number of new fish entering a population, is often measured to a point in the life cycle, such as, to young-ofthe-year, juvenile and adult (sexually mature) life-stages (Wootton 1998; King et al., 2013). Ultimately, the rate of successful recruitment to the mature population will determine longterm inter-generational population trends. Recruitment strength can be influenced by a range of biotic (e.g. competition, predation, disease) and abiotic (e.g. flow attributes, temperature, physical habitat) factors, with strong recruitment to the pool of reproductive individuals occurring only when combinations of such factors align (Nunn et al., 2007). Highly variable recruitment in space and time is a common characteristic of riverine fish populations, most likely due to the dynamic nature of the abiotic selective forces that act on lotic ecosystems (Biggs et al., 2005). Whilst biotic interactions such as predation have been demonstrated to have localised influences on recruitment (e.g. Myers et al., 1997), it is the abiotic environment that is most likely to have driven evolutionary development of specific ecological traits and associated life-history strategies (Lytle and Poff 2004; Biggs et al.,

This article is protected by copyright. All rights reserved. 
2005). Stream flow, in particular, is a major driver of lotic ecosystems. Hydrological characteristics can influence life history processes governing recruitment both directly (e.g. spawning and movement cues) and indirectly through the alteration of physical habitat attributes linked to survival. Specific mechanisms driving the latter include the well documented "flood pulse advantage" (Bayley 1991), whereby appropriately timed high flow events provide food rich floodplain habitats (and therefore increased survival) for many fish species occupying floodplain rivers. Conversely, for species occupying lower order highgradient streams, high flow events have been demonstrated to negatively affect survival, particularly of early life stages through mechanisms such as displacement or smothering of eggs (e.g. Lucas and Orth 1995; Smith et al., 2005; Milner et al., 2003) and decreased larval foraging success (e.g. Piccolo et al., 2008).

Understanding the dynamics and drivers of recruitment for fish species, particularly those which are long-lived, requires data collected over, or representative of temporal scales which are commensurate with species specific life history stages as well as capturing the natural range of abiotic conditions. Additional challenges arise when the species of interest is threatened (and therefore often rare in samples), resulting in datasets with small numbers and often over limited time periods, which may be inadequate to detect trends.

One way to help overcome such limitations is to compile information gathered from multiple populations at a regional scale. Regional or landscape-level processes often strongly influence local populations (Labbe and Fausch 2000), with many animal populations fluctuating in synchrony as a result (Koenig 2002). Potential driving forces of spatial 
synchrony include predation (Ims and Andreassen 2000), dispersal (Ranta et al., 1995), and environmental synchrony, otherwise known as the Moran effect (Moran 1953, Koenig 2002). The natural environment is a spatially auto-correlated place (Legendre 1993) and both biotic (e.g. population density, or reproductive rate) and abiotic (e.g. rainfall, flows and temperature) variables may at times similarly co-vary (Rossi et al., 1992; Liebhold et al., 2004). Thus, if dispersal and predation mechanisms can be dismissed as strong drivers, synchronous fluctuations in population processes such as recruitment by localised populations can potentially provide a useful tool to identify the influence of climatic effects on population dynamics (Tedesco et al., 2004; Nunn et al., 2007).

Over the past decade, research investigating the role of abiotic drivers, in particular streamflow, in governing fish recruitment has risen dramatically in Australia (King et al. 2013), likely due largely to the increasing application of environmental flows in river restoration. Much of this work has focussed on species occupying lowland floodplain river systems (e.g. Balcombe et al., 2012; Zampatti and Leigh 2013; Beesley et al., 2014; King et al., 2015), with less work on species and populations inhabiting headwater streams. One example of the latter is the Macquarie perch Macquaria australasica, which is a medium-sized (up to $465 \mathrm{~mm}$ Total length; Lintermans 2007), long-lived (up to 26 years; Tonkin et al., 2014) percichthyid fish, once widespread and abundant across the south-eastern reaches of the Murray-Darling Basin and several rivers of the eastern seaboard.

Macquarie perch has undergone major declines in distribution and abundance, and is now listed as nationally endangered under the Environmental Protection and Biodiversity

This article is protected by copyright. All rights reserved. 
Conservation Act 1999 (Commonwealth) and as threatened in the south-eastern state of Victoria under the Flora and Fauna Guarantee Act 1988 (Lintermans 2007; Tonkin et al., 2015). Populations are highly fragmented and span multiple catchments within its native range, occurring in isolated reaches of tributaries that contain remnant high quality habitat (Ingram et al. 2000; Lintermans 2007; DELWP unpublished data) (within the Goulburn, Broken, Mitta Mitta, Ovens, and Campaspe catchments). An additional population, in the mid-reaches of the Yarra River south of the Great Dividing Range, resulted from translocations of fish from the Mitta Mitta and Goulburn catchments from $1910-1940$ (Cadwallader 1981). Recent monitoring of some of these populations suggests poor recruitment is associated with years of large flow events during the core spawning period (late spring and early summer; King et al., 2011; Kearns et al., 2012; Tonkin et al., 2014). Considering fertilised Macquarie perch eggs settle and develop in riffle areas (Cadwallader and Rogan 1977; Ingram et al., 2000), it is likely that eggs and perhaps larvae are prone to disturbance which in turn, is reflected in recruitment strength. Nevertheless, this hypothesis has not been tested across multiple years or systems.

In this study, we describe recruitment dynamics of Macquarie perch across five isolated populations from south-eastern Australia and investigate these dynamics to drivers which fluctuate at local and regional scales. We hypothesise that large flow events during the breeding season (austral spring) disrupt the development of eggs and larvae, and hence reduce recruitment. Furthermore, because extremes in flow periods (e.g. droughts and wetter rainfall periods) tend to be associated with long-term, large-scale climate cycles (e.g.

This article is protected by copyright. All rights reserved. 
la niña events; Verdon et al., 2004), we hypothesise that if such events do supress recruitment, then recruitment patterns should vary synchronously among the isolated populations. In testing this hypothesis, we explicitly account for the size of the spawning population when considering the expected magnitude of recruitment. We then explore how our results may explain the current distribution patterns and risks to the species, and inform future management options such as the delivery of environmental flows and translocation actions.
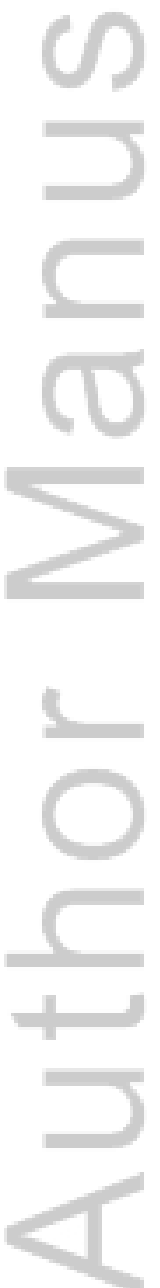

This article is protected by copyright. All rights reserved. 


\section{Methods}

Study sites and fish surveys

We investigated the recruitment dynamics of Macquarie perch by using a collective assessment of multi-year surveys of five populations across Victoria (Figure 1; Table 1). The maximum linear distance between the furthermost study regions, which lie within the south-eastern Australia, is approximately $245 \mathrm{~km}$ (Yarra River to Lake Dartmouth). The Yarra River, is a coastal stream approximately $240 \mathrm{~km}$ in length, draining a catchment of approximately 3,766 km² (DWR 1989). Boat- (Smith-Root ${ }^{\circledR}$ Model 5 GPP) and bank-(SmithRoot 7.5 Kva) mounted electrofishing surveys have been conducted at multiple sites between January -June during eight of the nine years from $2007-2015$. Whilst surveys were conducted at more than 40 sites over this time, juvenile Macquarie perch $(<150 \mathrm{~mm}$ $\mathrm{TL}$ ) were recorded only at 14 sites. Thus, for the purposes of this study (i.e. assessing recruitment), only these sites ( 8 - 14 sites per year) were used for our assessment. Electrofishing at each site was undertaken by using a standardised protocol developed for the Sustainable Rivers Audit (SRA; MDBC 2004). Briefly, at each site, 12 replicate (singlepass) 90 second electrofishing shots were conducted across all habitats within the river channel. Two of the fourteen sites were often sampled using Bank-mounted (Smith-Root 7.5 Kva) electrofishing using $10 \times 150$ second shots (SRA protocol) due to low flow periods.

Lake Dartmouth impounds the Mitta Mitta River and is the largest freshwater impoundment in south-eastern Australia's Murray-Darling Basin. The Lake, primarily an irrigation storage,

This article is protected by copyright. All rights reserved. 
has a surface area of 6380 ha and stores almost 4000000 ML of water at full capacity (Gray et al., 2000). Whilst Macquarie perch are naturally a riverine fish, the species has maintained a population in this reservoir, likely due to them having access to suitable inflowing riverine habitat for spawning and rearing (Cadwallader 1981; Appleford et al., 1998). Annual netting surveys of the Lake were undertaken over a five day period between February and May from 2010 to 2015. Between six to ten gill nets and four to six fyke nets were set for one overnight period across three sites in each of three regions of the Lake. Whilst numerous unregulated tributaries flow into Lake Dartmouth, the largest, the Mitta Mitta River (average annual discharge of approximately $800 \mathrm{ML}_{\text {day }}{ }^{-1}$ upstream of the Dam) is the primary spawning area used by Macquarie perch during their annual spring spawning migration out of the Lake (Douglas et al., 2002; Tonkin et al., 2010). Indeed, survey data have recorded early juvenile fish only in this region of the Lake, with fyke nets the primary method suited to the collection of juvenile fish ( $<150 \mathrm{~mm} \mathrm{TL})$. Thus, as per the Yarra River, only data collected within this region (and method) of the Lake were used for our assessment of recruitment.

King Parrot Creek, Hughes Creek and Sevens Creek are all unregulated tributaries of the Goulburn River located in north-eastern Victoria. Each has an annual average discharge of $40-60 \mathrm{ML} \mathrm{day}^{-1}$, draining a catchment of approximately $400-600 \mathrm{~km}^{2}$. Despite historical connectivity, anthropogenic alterations to flow (regulation and extraction), connectivity (dams and weirs) and land use (sedimentation) have resulted in highly fragmented habitats and subsequent isolation of Macquarie perch among the waterways (as reflected in recent 
genomic data; A. Pavlova, unpublished data). Annual surveys of King Parrot Creek were conducted between Feb - May from 2007 - 2015. Each year, between four and seven sites were sampled using a combination of $6-16$ fyke nets and $1000-1200$ seconds of backpack electrofishing (Smith-Root Model 12 or 20b). Backpack electrofishing surveys of Hughes Creek and Sevens Creek were conducted between January - May during six (Hughes; 5- 12 sites) and five (Sevens; $12-24$ sites) of the years between $2006-2015$. Sampling of all sites in both Hughes Creek and Sevens Creek consisted of defined distances and / or electrofishing seconds fished (recorded at all sites).

For each of the populations, all sampling was conducted during periods of relatively stable low flow conditions to minimise detection bias. All fish captured were weighed (to the nearest gram) and measured for total length (TL; nearest millimetre) before release.

\section{Analyses}

Recruitment strength was investigated by using annual counts of young-of-year (YOY; fish less than 1 year of age). YOY fish were identified based on recently published length-age relationships for lacustrine (Dartmouth population) and riverine populations (all other populations; Tonkin et al., 2014; see supplementary material 1). In brief, a standard nonlinear regression model (Gompertz) of length $\mathrm{Lx}(\mathrm{mm})$ at age $X$ (years) was constructed from known aged individuals to enable estimates of age from length data. Specifically:

Gompertz: $L_{x}=L_{\infty} e^{e^{(-b(X-M))}}$

This article is protected by copyright. All rights reserved. 
Where $L X$ is the length at age $X, L \infty$ is the asymptotic length, $b$ is the instantaneous growth rate, and $\mathrm{M}$ is the inflection point of the curve (years).

Although the outputs of the growth models were primarily to distinguish YOY fish as a measure of recruitment, a secondary output was the identification of adult (mature) fish, defined as $>4$ years of age (Appleford et al., 1998) to provide estimates of spawning stock abundance, which is also likely to influence recruitment strength (Nunn et al., 2007).

For the purpose of examining annual fluctuations in recruitment among rivers, we pooled data from multiple sites within each river to create a time-series of abundance of YOY fish for each stream, standardised for survey effort (offset against the total number of nets or electrofishing seconds in a given year; see below). We then compiled complementary timeseries of (primarily) environmental data considered as likely candidates to explain recruitment variability (Table 2). Of particular interest was our hypothesis of a negative association between Macquarie perch recruitment strength and flow magnitude and/or variability during the core period of egg and larval developmental (November - December; Tonkin et al., 2015). River (used as a factor in the model to account for localised drivers); Pre- and post- spawning flows (named accordingly); spawning season water temperature $\left(S P_{-}\right.$TEMP); spawning stock abundance (standardised count of mature fish; PS_SSA) and river height (PS_RIV_HEIGHT) at the time of sampling (as a proxy for conditions which may influence sampling detection), were also variables considered in our suite of hypotheses (Table 2).

This article is protected by copyright. All rights reserved. 
Whilst there are several mechanistic drivers which may govern our flow dependent hypotheses (e.g. turbidity and change depth), egg and larval disturbance is most likely to be related to water velocity (and its change; e.g. Smith et al., 2005). Unfortunately, sitespecific data on this metric was not readily available. Nevertheless, for lower order streams, there is a strong correlation between velocity and the most common metric of hydrological gauging, discharge. Thus, we generated flow and temperature variables using daily discharge and temperature (if available) values from permanent gauging stations in close proximity to each of the sample sites (Yarra River at Templestowe; Dartmouth = Mitta Mitta River at Hinnomunji Bridge; King Parrot Creek at Flowerdale; Hughes Creek at Tarcombe Rd; Sevens Creek at Polly McQuinn weir). Unfortunately, continuous records of daily water temperature were unavailable for the King Parrot Creek, Hughes Creek and Sevens Creek. We did, however, have temperature data collected during several spawning seasons using an in-situ temperature logger in the King Parrot Creek. Simple linear models have been used successfully to model water temperature using air temperature and /or other independent variables (see Benyahya et al. 2007). As such, we used minimum daily air temperature, average daily flow, month and day of month in combination with our water temperature data in a linear model to predict average daily water temperatures during the core spawning season for the King Parrot Creek, Hughes Creek and Sevens Creek (see supplementary material 2 for model parameters).

Generalised Linear Models (GLM's), using a negative binomial distribution due to the nonnormal distribution of YOY count data (and to address over-dispersion associated with 
Poisson distributed models) were used to analyse the data. The total count of YOY in a given year was standardised (offset) by the total effort applied in the surveys of that year (number of nets or electrofishing seconds standardised for each system). We then fitted a suite of additive models using combinations (of low correlation values; Pearson's correlation coefficient) of the aforementioned variables relating to our hypothesised drivers of Macquarie perch recruitment (Table 3). The relative support for each model was assessed by using Akaike's Information Criterion (AIC), corrected for small sample size (AICC) (Burnham and Anderson, 1998). AICc values were rescaled as differences between each model and the model with the lowest AICc value. The final model was checked for overdispersion and goodness of fit by using a $\chi 2$-test based on residual deviance and degrees of freedom. All models were fitted using the $R$ statistical programming environment $(R$ Development Core Team 2013), with all GLM's constructed using the package MASS (Venables and Ripley, 2002).

\section{Results \\ Environmental variables}

All of the study waterways exhibited highly correlated patterns in seasonal discharge across years (Pearson's pairwise correlation coefficients of 0.704-0.998; Figure 2; Supplementary material 3). Specifically, the six year period from 2007 - 2012 was a period of highly variable annual discharges, with four years of extreme low and two years of very high flows

This article is protected by copyright. All rights reserved. 
respectively. These extremes were most pronounced in the smaller waterways as compared to the Yarra and Mitta Mitta Rivers (Figure 2). The following three years consisted of relatively average to low flows (2013 - 2015). Whilst all discharge variables displayed strong correlations between waterways, there was a general trend of strongest correlations between the three smallest waterways (and closest proximity) in the Goulburn catchment (see supplementary material 3 for details).

Both temperature and flow variability during the spawning period exhibited more localised patterns, with higher variation between waterways. In 2011, mean daily water temperatures during the spawning period (Oct - Dec) were low across all waterways $(<15$ $\left.{ }^{\circ} \mathrm{C}\right)$. Other extremes in temperature during this period were most similar between the Goulburn systems and the Mitta Mitta River (Lake Dartmouth spawning tributary), with the Yarra River the most different (Figure 2a; Supplementary material 3f). Our flow variability metric during the peak egg and larval period (days of discharge change $>100 \%$ ) was similar between the Goulburn systems but not the other systems (Supplementary material 3e). All annual discharge values (excluding change in flow) within systems were strongly correlated (>0.75; Supplementary material 4). As such, only one discharge variable could be included in each of the model structures (see below).

Recruitment dynamics

This article is protected by copyright. All rights reserved. 
Counts of Macquarie perch YOY recorded across rivers from 2007-2015 were in general, higher in the 2010 and 2015 sample years (indicative of fish spawned the previous spring; Figure 3). Conversely, the 2011 and 2012 survey years (those of highest discharge and low temperatures during the preceding spring spawning period) were years of low recruitment for all surveyed populations. Our selection procedure, indicated that model 11 provided the best explanation of YOY abundance relative to other models (Table 3; Chi-Square goodness of fit test $P=0.615)$. The effects of discharge during November - December (SP_DIS_NovDec); and spawning stock abundance (PS_SSA) were the covariates considered the most important in explaining variations in recruitment strength (Model 11). The parameter estimates and subsequent predictions of model 11 indicated a significant negative relationship between YOY abundance and SP_DIS_Nov-Dec (Figure 4; $p<0.001$; GLM coefficient estimates of -1.525); and significant positive relationship between YOY abundance and spawning stock abundance (Figure 4; $<<0.01 ;$ GLM coefficient estimates of $0.7133)$

There was also some support for the more complex models (12 and 15) which included the addition of our measure of flow variability during November - December (SP_DAYS>100) and average daily water temperature during October - December (SP_TEMP). The effects of these covariates on YOY abundance were negative and positive, respectively (GLM coefficient estimates of -0.017 and 0.243 , respectively), but their effects were minor and not significant (both $\mathrm{p}>0.05$ ). None of the best supported models included the Factor River, indicating the response to flows was similar across systems and suggests the effects of more

This article is protected by copyright. All rights reserved. 
local variables (not identified in the analyses) on recruitment dynamics were minor in comparison to discharge, which was highly correlated across the region.

Our predictions of YOY abundance for each of the study rivers from 2007 - 2015 provides some support for spatial synchrony in recruitment strength, with a general trend of decreasing recruitment strength from 2007 - 2012, followed by an increase in recruitment strength in the 2013 - 2015 sample years (spawned in the previous spring; Figure 5). Trends in recruitment dynamics were most similar for the three Goulburn populations (Figures 5b. d. and e. respectively). Unlike all other populations, the levels of recruitment in the Yarra population were somewhat dampened, having not yet approached (or exceeded) the levels predicted at the start of the sampling period in 2007 (Figure 5.).

This article is protected by copyright. All rights reserved. 


\section{Discussion}

To our knowledge this study is the first to demonstrate a broad-scale correlation between regional-scale flow variability and localised recruitment dynamics of fish in south-eastern Australia. It also provides a greater understanding of the spatiotemporal recruitment dynamics of an endangered riverine fish, demonstrating the role of a local-scale biotic variable (spawning stock abundance), and an abiotic variable (discharge) which was highly correlated at a regional scale.

Our multi-population analyses demonstrated poorer recruitment in years of higher discharge during the core egg and larval period (November - December). This finding is not in itself surprising; recruitment of freshwater fishes is known to be affected dramatically by episodic adverse physical or chemical conditions (Houde 1989; King et al., 2013). In particular, changes in water velocity and temperature have significant effects on the survival of eggs and larvae (Simonson and Swenson 1990; Mion et al., 1998; Paul 2012; Suedel et al., 2012). For fish species occupying lower order high-gradient streams, extreme high flows during critical reproductive periods has been demonstrated to negatively affect recruitment strength of numerous fish species (e.g. Freeman et al., 2001; Nicola et al., 2009). Specific mechanisms of how such flows reduce recruitment success could include nest or redd scour (e.g. Lucas and Orth 1995; Smith et al., 2005), siltation of egg incubation substrate (Milner et al., 2003), displacement of larvae (e.g. Simonson and Swenson 1990), loss of critical nursery habitat (Freeman et al., 2001), and high turbidity and velocity which decreases larval foraging success (Piccolo et al., 2008). Such mechanisms are theoretically relevant to the

This article is protected by copyright. All rights reserved. 
early life- history characteristics of Macquarie perch where fertilised eggs settle into riffle areas to ensure maximum aeration and minimise the risk of smothering by sediments (Cadwallader and Rogan 1977; Ingram et al., 2000).

Including the abundance of spawning stock into the model significantly improved the ability to predict recruitment strength. Specifically, years of high spawning stock abundance translated to years of high recruitment, particularly when coinciding with favourable flow conditions. Nunn et al., (2007) pointed out that even if environmental conditions are ideal, recruitment strength will still be low if only a small number of adults are available for spawning. We suggest that drought conditions from 2007 to 2011 reduced adult population sizes in several of the smaller and more drought susceptible tributaries (especially Hughes and Sevens (reek systems), and that this translated into an overall decreasing trend in recruitment at those sites even though per capita recruitment rates may have been relatively high. This is an example of the clear relationship between biotic interactions, population dynamics and abiotic components (Power et al., 1988; Jackson et al., 2001). Whilst the status of a population's spawning stock is fundamental to understanding its dynamics (Wootton 1998), this factor is often overlooked in favour of considering only abiotic variables under the premise that they have the greatest effects on survival (e.g. Milner et al., 2003). Our results reinforce this fundamental aspect of fisheries management, emphasising the need to account for this important biotic driver to gain a complete understanding of recruitment dynamics. This result also highlights the importance of conserving adult fish stocks, both through careful management of the recreational fishery

This article is protected by copyright. All rights reserved. 
and safeguarding against extreme events (e.g. adult translocation from the King Parrot Creek following bushfire sedimentation events; Kearns et al., 2012).

Stream landscapes are highly variable in space as well as time, with a general pattern of increasing stability of fish populations down a watershed gradient (Matthews 1986) attributed to increased stability of stream flow (Taylor and Warren 2001). Whilst speciesspecific responses to abiotic drivers are likely to be similar across populations, the relative importance of the driver is likely to vary among waterbodies. Nunn et al., (2007) indicated that whilst temporal variation occurs because of inter-annual differences in river discharge relative to the timing of fish hatching (as per the findings of the current study), river discharge is likely to be of relatively greater importance in rivers which are prone to large and rapid fluctuations in flow.

The rivers used in this study have comparatively variable patterns in discharge, with the larger Yarra River and Dartmouth system (Mitta Mitta River) displaying lower variation compared to the smaller Goulburn tributaries. Interestingly, to some degree this pattern was also mirrored in patterns of recruitment strength. For example, average daily discharge variability in King Parrot Creek during November-December (using data from 1961 - 2015, inclusive) is more than twice that of the Mitta Mitta River (CV = 2.098 and 0.956, respectively). Smaller systems are also more likely to experience greater variability in adult fish abundance as a result of increased vulnerability to stochastic events such as extreme drought, flood and bushfire (Kearns et al., 2011; Lintermans 2013a). It could therefore be expected that these remnant and now isolated populations of Macquarie perch exhibit less

This article is protected by copyright. All rights reserved. 
stable recruitment patterns, and a reduced resilience to environmental extremes, particularly those which are likely to be exacerbated by climate change (as predicted by Balcombe et al., 2011).

Our investigation of recruitment patterns across five isolated populations of Macquarie perch also revealed some evidence of spatial synchrony. One explanation for this covariance is through the process of dispersal (e.g. Ranta et al., 1995), but this mechanism is highly unlikely given the isolation (resulting from human induced flow, passage and land use alterations) of our populations. We propose these observations are a result of the Moran effect (Moran 1953), whereby biotic (in this case recruitment strength) and abiotic (such as rainfall, flows and temperature) patterns co-vary across space (landscape and regional scales) and time (Rossi et al., 1992; Liebhold et al., 2004). Indeed, the recruitment dynamics of fish populations are often predictable along environmental gradients (Tedesco et al., 2004; Nunn et al., 2007). For example, the correlation scale for recruitment of marine species is typically $500 \mathrm{~km}$ whereas for freshwater species, it has been reported to range from 50 to $400 \mathrm{~km}$ (Myers et al., 1997; 2015; Chevalier et al., 2015). Whilst we performed no formal analyses of the spatial scales of such patterns, our observations are consistent with such patterns, with the linear distance between our furthermost sites (Yarra River and Lake Dartmouth) being approximately $250 \mathrm{~km}$. Our study has also demonstrated that when dispersal mechanisms can be dismissed (as was the case for the isolated populations used in this study), the Moran Effect is a useful theory to help identify the key regional scale drivers of population variation. Given the extreme fluctuations in recruitment strength for this

This article is protected by copyright. All rights reserved. 
endangered species can be explained by large-scale factors (like regional scale fluctuations in flow), future management and conservation activities for the species will be made easier by integrating broad-scale climate forecasts particularly during extreme events such as extended droughts and flood.

Other variables are also likely to influence recruitment dynamics of riverine fish like Macquarie perch, particularly at local scales. For example, despite a relatively weak statistical effect, both temperature and our flow change parameter (both more localised effects), had some support for inclusion in our model selection process. Specifically, temperature during the spawning period had a positive association with Macquarie perch recruitment, conforming to patterns reported in spawning activity in both lacustrine (Cadwallader and Rogan 1977; Tonkin et al., 2010) and riverine populations (Tonkin et al., 2014). Secondly, there was a weak negative association between recruitment strength and flow change (equating to rapid changes in velocity) during the core egg and larval period. Other examples of localised drivers that influence Macquarie perch recruitment and / or populations include recreational harvest (e.g. Hunt et al., 2011); and major habitat alterations that prevent access to key spawning habitat (Broadhurst et al., 2013).

Our findings have implications for efforts to conserve this threatened species. A first step in threatened species recovery actions is to define critical habitat requirements for the species, thus informing habitat management and site selection for actions such as translocation (Foin et al., 1998; Labbe and Fausch 2000). The results suggest conservation actions for Macquarie perch may be best targeted at maintaining or re-establishing 
populations using hatchery reared fingerlings or translocations from wild populations (e.g. Todd and Lintermans 2015) into higher-order streams where hydraulic variation is lower, habitat characteristics are more stable and communities are able to persist for relatively longer periods of time (Jackson et al., 2014).This differs from past stocking strategies for the species across Victoria, whereby fingerlings have been released into what were largely small low-order streams, with minimal success (Cadwallader 1981).

Managing river flows, including the use of environmental water, is another intervention increasingly being used to restore native fish populations, and is currently in use in the Yarra River (for Macquarie perch and other species; Tonkin et al., 2015). Whilst the delivery of environmental flows during the reproductive period is used to stimulate the spawning of some native fish (e.g. King et al., 2015), our results suggest that managing water delivery to avoid great increases in discharge during the spawning period will provide the best outcomes for Macquarie perch recruitment. We propose that if environmental water is to be used to sustain or enhance Macquarie perch, it should be targeted at other time periods to enhance other important population processes such as growth, survival and condition of juvenile and/or adult fish (the importance of the latter being emphasised in the current study). The maintenance of summer base flows during drought periods, or improving growth and condition of adults are logical choices based on our finding of the importance of adult stock abundance as a driver of recruitment strength (see also Lintermans 2013b; Tonkin et al., 2014).

This article is protected by copyright. All rights reserved. 
This study has improved the understanding of the role of both regional-scale variation in river flows and more localised abundance of spawning stock in governing recruitment dynamics of the endangered Macquarie perch. The synchronised patterns in recruitment observed across the isolated populations in this study suggest the importance of large-scale climatic patterns as a driver of annual variation in recruitment. This could also apply to other long-lived freshwater species with similar life histories to Macquarie perch. Importantly, regional-scale population synchrony highlights the vulnerability of these otherwise isolated populations to simultaneous declines, increasing the risk of regional populations becoming imperilled (e.g. Chevalier et al., 2015). Thus, effective conservation of threatened freshwater fishes like Macquarie perch which have been reduced to small isolated populations will require a coordinated, multijurisdictional approach as is the case for many terrestrial species (Labbe and Fausch 2000).



This article is protected by copyright. All rights reserved. 


\section{Acknowledgements}

We thank Melbourne Water (Helen Clarke), the Goulburn- Broken Catchment Management Authority (Wayne Tennent and Mark Turner) and Fisheries Victoria (Anthony Forster) for project funding, support and provision of data. Thanks to the numerous staff from the Arthur Rylah Institute: in particular Justin O’Mahony, Andrew Pickworth, John Mahoney, Scott Raymond, Renae Ayres, Graeme Hackett, Kris Pitman for field assistance; Paul Moloney and Charles Todd provided valuable guidance on statistical analyses and robust discussion and; Professor Andrew Bennett for comments on draft reviews. Jon McGuckin and Tom Ryan are also thanked for their contribution to surveys of the Yarra River. This work was carried out und the Victorian Fisheries Research Permit RP827, FFG Research Permit 10005913/10007273 and animal ethics approval 12/03.

This article is protected by copyright. All rights reserved. 


\section{References}

Appleford P, Anderson TA, Gooley GJ. 1998. Reproductive cycle and gonadal development of Macquarie perch, Macquaria australasica Cuvier (Percichthyidae), in Lake Dartmouth and tributaries of the Murray-Darling Basin, Victoria, Australia. Marine and Freshwater Research 49 : 163-9.

Arthington AH, Balcombe SR. 2011. Extreme flow variability and the 'boom and bust'ecology of fish in arid-zone floodplain rivers: a case history with implications for environmental flows, conservation and management. Ecohydrology 4 : 708-720.

Balcombe SR, Arthington AH, Thoms MC, Wilson G. 2011. Fish assemblage patterns across a gradient of flow regulation in an Australian dryland river system. River Research and Applications 27 : 168-183.

Balcombe SR, Lobegeiger JS, Marshall SM, Marshall JC, Ly D, Jones DN. 2012. Fish body condition and recruitment success reflect antecedent flows in an Australian dryland river. Fisheries Science 78 : 841-847.

Beesley LS, Gwinn DC, Price A, King AJ, Gawne B, Koehn JD, Nielsen DL. 2014. Juvenile fish response to wetland inundation: how antecedent conditions can inform environmental flow policies for native fish. Journal of Applied Ecology 51 : 1613-1621.

Benyahya L, Caissie D, St-Hilaire A, Ouarda TB, Bobée B. 2007. A review of statistical water temperature models. Canadian Water Resources Journal 32 : 179-192.

This article is protected by copyright. All rights reserved. 
Biggs BJF, Nikora VI, Snelder TH. 2005. Linking scales of flow variability to lotic ecosystem structure and function. River Research and Applications 21 : 283-298.

Broadhurst BT, Ebner BC, Lintermans M, Thiem JD, Clear RC. 2013. Jailbreak: a fishway releases the endangered Macquarie perch from confinement below an anthropogenic barrier. Marine and Freshwater Research 64 : 900-908.

Cadwallader PL, Rogan PL. 1977. The Macquarie perch, Macquaria australasica (Pisces: Percichthyidae) of Lake Eildon, Victoria. Australian Journal of Ecology 2, 409-18.

Cadwallader PL. 1981. Past and present distributions and translocations of Macquarie Perch Macquaria australasica (Pisces: Percicthyidae), with particular reference to Victoria. Proceedings of the Royal Society of Victoria 93 : 23-30.

Chevalier M, Laffaille P, Ferdy JB, Grenouillet G. 2015. Measurements of spatial population synchrony: influence of time series transformations. Oecologia 179 : 15-28.

Douglas J, Giles A, Strongman R. 2002. Lake Dartmouth multi-species fishery assessment. Marine and Freshwater Resources Institute Freshwater Fisheries Report No. 02/2. Faulks LK, Gilligan DM, Beheregaray LB. 2011. The role of anthropogenic vs. natural instream structures in determining connectivity and genetic diversity in an endangered freshwater fish, Macquarie perch (Macquaria australasica). Evolutionary applications 4 : $589-601$.

Foin TC, Riley SPD, Pawley AL, Ayres DR, Carlsen TM, Hodum PJ, Switzer PV. 1998. Improving recovery planning for threatened and endangered species. Bioscience 48, 177-184.

This article is protected by copyright. All rights reserved. 
Freeman MC, Bowen ZH, Bovee KD, Irwin ER. 2001. Flow and habitat effects on juvenile fish abundance in natural and altered flow regimes. Ecological Applications 11 : 179-190.

Ginzburg LR. 1986. The theory of population dynamics: I. Back to first principles. Journal of Theoretical Biology 122 : 385-399.

Gray SC, De Silva SS, Ingram BA, Gooley GJ. 2000. Effects of river impoundments on body condition and reproductive performance of the Australian native fish, Macquarie perch (Macquaria australasica). Lakes \& Reservoirs: Research and Management 5 : 281-291. Harris JH, Bond N, Closs GP, Gerhke PC, Nicol SJ, Ye Q. 2013. Dynamics of Populations. In Ecology of Australian Freshwater Fishes. (Eds. H P. and K Walker) pp. 223-244. (CSIRO Publishing: Melbourne).

Houde ED. 1989. Subtleties and episodes in the early life of fishes. Journal of Fish Biology 35 :29-38.

Hunt TL, Douglas JW, Allen MS, Gwinn DC, Tonkin Z, Lyon J, Pickworth A. 2011. Evaluation of population decline and fishing sustainability of the endangered Australian freshwater fish Macquaria australasica. Fisheries Management and Ecology 18 : 513-520.

Ims RA, Andreassen HP. 2000. Spatial synchronization of vole population dynamics by predatory birds. Nature 408 : 194-196.

Ingram BA, Douglas JW, Lintermans M. 2000. Threatened fishes of the world: Macquaria australasica Cuvier, 1830 (Percichthyidae). Environmental Biology of Fishes 59 : 68. DOI:10.1023/ A:1007669423532

This article is protected by copyright. All rights reserved. 
Jackson DA, Peres-Neto PR, Olden JD. 2001. What controls who is where in freshwater fish communities the roles of biotic, abiotic and spatial factors. Canadian Journal of Fisheries and Aquatic Sciences 58 : 157-170.

Junk W., Bayley PB, Sparks RE. 1989. The flood pulse concept in river-floodplain systems. Canadian Special Publication of Fisheries and Aquatic Sciences 106, 110-27.

Kearns J, Ayres R, O’Mahony J, Hackett G, Lyon J. 2011. An investigation into Macquarie perch and trout cod populations in the Goulburn-Broken Catchment and their response to increased flows during 2010/2011. Confidential Client Report prepared for the GoulburnBroken Catchment Authority. Department of Sustainability and Environment,

Melbourne.

Kearns J, Tonkin Z, O'Mahony J, Lyon J. 2012. Identification and protection of key spawning habitats for Macquarie perch in King Parrot Creek: Black Saturday Victoria 2009 - Natural values fire recovery program. Department of Sustainability and Environment, Heidelberg, Victoria.

King AJ, Tonkin Z, Mahoney J, Raymond S. 2011. Spawning and recruitment of the Yarra River's Endangered Macquarie Perch Macquaria australasica population - 2010 / 2011. Arthur Rylah Institute for Environmental Research Client Report, Department of Sustainability and Environment, Heidelberg, Victoria.

This article is protected by copyright. All rights reserved. 
King AJ, Humphries P, McCasker NG 2013. Reproduction and early life history. In Ecology of Australian Freshwater Fishes. (Eds. H P. and K Walker) pp. 159-193. (CSIRO Publishing: Melbourne)

King AJ, Gwinn DC, Tonkin Z, Mahoney J, Raymond S, Beesley L. 2015. Using abiotic drivers of fish spawning to inform environmental flow management. Journal of Applied Ecology 53 :

34-43. DOI: 10.1111/1365-2664.12542

Koenig WD. 2002. Global patterns of environmental synchrony and the Moran effect.

Ecography 2 : 283-288.

Labbe TR, Fausch KD. 2000. Dynamics of intermittent stream habitat regulate persistence of a threatened fish at multiple scales. Ecological Applications 10 : 1774-1791.

Legendre P. 1993. Spatial autocorrelation: Trouble or new paradigm? Ecology 74 : 16591673.

Liebhold A, Koenig WD, Bjørnstad ON. 2004. Spatial synchrony in population dynamics. Annual Review of Ecology, Evolution, and Systematics : 467-490.

Lintermans M. 2007. Fishes of the Murray-Darling Basin: An introductory guide. Murray Darling Basin Commission, Canberra, ACT.

Lintermans M. 2013a. The rise and fall of a translocated population of the endangered Macquarie perch, Macquaria australasica, in south-eastern Australia. Marine and Freshwater Research 64 : 838-850.

This article is protected by copyright. All rights reserved. 
Lintermans M. 2013b. A review of on-ground recovery actions for threatened freshwater fish in Australia. Marine and Freshwater Research 64 : 775-791.

Lytle DA, Poff NL. 2004. Adaptation to natural flow regimes. Trends in Ecology and Evolution $19: 94-100$.

Matthews WJ. 1986. Fish faunal structure in an Ozark stream: stability, persistence and a catastrophic flood. Copeia $1986: 388-397$.

Milner NJ, Elliott JM, Armstrong JD, Gardiner R, Welton JS, Ladle M. 2003. The natural control of salmon and trout populations in streams. Fisheries Research $62: 111-125$.

Mion JB, Stein RA, Marschall EA. 1998. River discharge drives survival of larval walleye. Ecological Applications 8 : 88-103.

Moran PAP. 1953. The statistical analysis of the Canadian Iynx cycle. II. Synchronization and meteorology. Australian Journal of Zoology 1 : 291-298.

Myers RA, Mertz G, Bridson J. 1997. Spatial scales of interannual recruitment variations of marine, anadromous, and freshwater fish. Canadian Journal of Fisheries and Aquatic Sciences 54 : 1400-1407.

Myers JT, Yule DL, Jones ML, Ahrenstorff TD, Hrabik TR, Claramunt RM, Ebener MP, Berglund EK. 2015. Spatial synchrony in cisco recruitment. Fisheries Research 165 : 11-21. Nicola G, Almodóvar A, Elvira B. 2009. Influence of hydrologic attributes on brown trout recruitment in low-latitude range margins. Oecologia 160 : 515-524.

This article is protected by copyright. All rights reserved. 
Nunn AD, Harvey JP, Britton JR, Frear PA, Cowx IG. 2007. Fish, climate and the Gulf Stream: the influence of abiotic factors on the recruitment success of cyprinid fishes in lowland rivers. Freshwater Biology 52 : 1576-1586.

Paul AJ. 2012. Environmental flows and recruitment of walleye (Sander vitreus) in the Peace-Athabasca Delta. Canadian Journal of Fisheries and Aquatic Sciences 70 : 307-315.

Piccolo JJ, Hughes NF, Bryant MD. 2008. Water velocity influences prey detection and capture by drift-feeding juvenile coho salmon (Oncorhynchus kisutch) and steelhead (Oncorhynchus mykiss irideus). Canadian Journal of Fisheries and Aquatic Sciences 65 : 266275.

Power ME, Stout RJ, Cushing CE, Harper PP, Hauser FR, Matthews WJ, Moyle PB, Statzner B, Wais De Badgen IR. 1988. Biotic and abiotic communities. Journal of the North American Benthological Society 7 : 1-25.

Ranta E, Kaitala V, Lindstrom J, Linden H. 1995. Synchrony in population dynamics. Proceedings of the Royal Society of London. Series B: Biological Sciences 262 : 113-118.

Rossi RE, Mulla DJ, Journel AG, Franz EH. 1992. Geostatistical tools for modeling and interpreting ecological spatial dependence. Ecological monographs 62 : 277-314.

Simonson TD, Swenson WA. 1990. Critical stream velocities for young-of-the-year smallmouth bass in relation to habitat use. Transactions of the American Fisheries Society 119 : 902-9.

This article is protected by copyright. All rights reserved. 
Suedel BC, Lutz CH, Clarke JU, Clarke DG. 2012. The effects of suspended sediment on walleye (Sander vitreus) eggs. Journal of Soils and Sediments 12 : 995-1003.

Taylor CM, Warren ML. 2001. Dynamics in species composition of stream fish assemblages: environmental variability and nested subsets. Ecology $82: 2320-2330$.

Tedesco PA, Hugueny B, Paugy D, Fermon Y. 2004. Spatial synchrony in population dynamics of West African fishes: a demonstration of an intraspecific and interspecific Moran effect. Journal of Animal Ecology 73 : 693-705.

Todd CR, Lintermans M. 2015. Who do you move? A stochastic population model to guide translocation strategies for an endangered freshwater fish in south-eastern Australia.

Ecological Modelling 311 : 63-72.

Tonkin Z, Lyon J, Pickworth A. 2010. Spawning behaviour of the endangered Macquarie Perch Macquaria australasica in an upland Australian river. Ecological Management and Restoration 11 : 223-226.

Tonkin Z, Lyon J, Ramsey D, Bond N, Hackett G, Krusic-Golub K, Ingram BA, Balcombe S. 2014. Reservoir refilling enhances growth and recruitment of an endangered remnant riverine fish. Canadian Journal of Fisheries and Aquatic Sciences. 71 : 1888-1899.

Tonkin Z, Kearns J, O’Mahony J, Mahoney J. 2015. Spatio-temporal spawning patterns of two riverine populations of the threatened Macquarie perch (Macquaria australasica). Marine and Freshwater Research. http://dx.doi.org/10.1071/MF15319

Venables WN, Ripley BR. 2002. Modern Applied Statistics Using S-Plus, fourth ed.

This article is protected by copyright. All rights reserved. 
Springer-Verlag.

Verdon DC, Wyatt AM, Kiem AS, Franks SW. 2004. Multidecadal variability of rainfall and streamflow: Eastern Australia. Water Resources Research 40

Wootton RJ. 1998. 'Ecology of Teleost Fishes.' 2nd edition edn. (Kluwer Academic Publishers: Dordrecht) 386 pp

Zampatti B, Leigh S. 2013. Effects of flooding on recruitment and abundance of Golden Perch (Macquaria ambigua ambigua) in the lower River Murray. Ecological Management \& Restoration 14 : 135-143.

This article is protected by copyright. All rights reserved. 
Table 1. Summary of the annual sampling protocol for each of the Macquarie perch population monitoring programs.

\begin{tabular}{|c|c|c|c|}
\hline Population (system) & Date & Site No. year ${ }^{-1}$ & Methods \\
\hline Yarra River & 2007, $2009-2015$ & $8-14$ & $\begin{array}{l}\text { Boat- and bank-mounted } \\
\text { electrofishing; } 12 \text { × } 90 \mathrm{sec} \text { shots } \\
\text { site }^{-1}\end{array}$ \\
\hline Lake Dartmouth & $2010-2015$ & 3 & Fyke netting; $3-12$ nets per site \\
\hline King Parrot Creek & $2008-2015$ & $4-7$ & $\begin{array}{l}\text { Backpack electrofishing / Fyke net } \\
\text { combination; Approx. } 1000 \text { sec. and } \\
10 \text { nets site }{ }^{-1}\end{array}$ \\
\hline Hughes Creek & $\begin{array}{l}2007,2011-2013 \\
2015\end{array}$ & $5-12$ & $\begin{array}{l}\text { Backpack electrofishing; Approx. } \\
1000 \text { sec. site }{ }^{-1}\end{array}$ \\
\hline Sevens Creek & $\begin{array}{l}\text { 2007-2009, 2011, } \\
2015\end{array}$ & $12-24$ & $\begin{array}{l}\text { Backpack electrofishing; Approx. } \\
1000 \text { sec. site }{ }^{-1 *}\end{array}$ \\
\hline
\end{tabular}

* Electrofishing seconds variable across sites and years.

This article is protected by copyright. All rights reserved. 
Table 2. Variables used to predict Macquarie perch recruitment strength using generalised linear models. Description and associated hypotheses of each also provided. Note: SP variables are those largely affecting the spawning period, PS are those largely affecting the postspawning periods.

\begin{tabular}{|c|c|c|}
\hline Variable & Description & Hypothesis \\
\hline RIVER & Study River & $\begin{array}{l}\text { Responses in recruitment strength will be dependent on the specific } \\
\text { waterway }\end{array}$ \\
\hline SP_DIS_Nov-Dec & Average daily discharge (November - December) & $\begin{array}{l}\text { High discharge during core egg and larval development period will } \\
\text { decrease survival and therefore recruitment strength }\end{array}$ \\
\hline SP_TEMP & $\begin{array}{l}\text { Average daily water temperature } \\
\text { (October_December) }\end{array}$ & $\begin{array}{l}\text { Higher water temperatures during core spawning and early } \\
\text { development period will increase egg and larval survival and therefore } \\
\text { recruitment strength }\end{array}$ \\
\hline SP_DAYS $>100$ & $\begin{array}{l}\text { Number of days when discharge increases by more } \\
\text { than } 100 \% \text { from the previous day (November - } \\
\text { December) }\end{array}$ & $\begin{array}{l}\text { Increased hydraulic variability during core egg and larval development } \\
\text { period will decrease survival and therefore recruitment strength }\end{array}$ \\
\hline SP_DIS_Sep-Oct & Average daily discharge (September - October) & $\begin{array}{l}\text { High discharge in early spring will enhance migration and/or spawning } \\
\text { substrate (riffle) condition and therefore recruitment strength. }\end{array}$ \\
\hline PS_DIS_Dec-Mar & Average daily discharge (December - March) & Summer flows will influence habitat availability / survival of juveniles \\
\hline PS_SSA & $\begin{array}{l}\text { Spawning stock abundance calculated as the average } \\
\text { annual abundance of mature fish ( }>4 \text { years of age) }\end{array}$ & $\begin{array}{l}\text { Higher numbers of mature adults in system will increase overall } \\
\text { reproductive output and subsequent recruitment strength }\end{array}$ \\
\hline PS_RIV_HEIGHT & River height at time of sampling & $\begin{array}{l}\text { Higher river levels during sampling will decrease detection of juvenile } \\
\text { fish }\end{array}$ \\
\hline 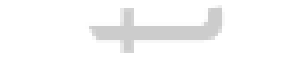 & & \\
\hline
\end{tabular}

This article is protected by copyright. All rights reserved. 


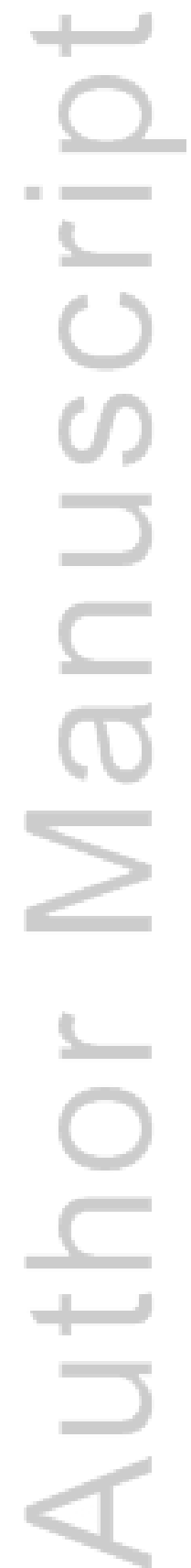

This article is protected by copyright. All rights reserved. 
Table 3. Results of the model selection procedure for 24 additive models comparing the effects of river, discharge, temperature, spawning stock abundance (SSA) and sampling condition variables on Macquarie perch Young-of-year (YOY) abundance across five Victorian rivers between 2007 - 2015. AIC Akaike's Information Criterion (c, corrected for small sample size); $\triangle \mathrm{AICc}$, difference in $\mathrm{AICc}$ between this model and the model with the lowest AICc.

\begin{tabular}{|c|c|c|c|c|}
\hline Model no. & Model & AICc & d.AICc & Likelihood \\
\hline 1 & YOY River + SP_TEMP & 237.564 & 20.083 & 0.000 \\
\hline 2 & YOY River + SP_DIS_Nov-Dec & 223.021 & 5.540 & 0.030 \\
\hline 3 & "YOY River + SP_DIS_Nov-Dec + SP_TEMP & 226.081 & 8.600 & 0.006 \\
\hline 4 & YOY SP_TEMP & 234.676 & 17.195 & 0.000 \\
\hline 5 & YOY SP_DIS_Nov-Dec & 222.767 & 5.286 & 0.034 \\
\hline 6 & YOY SP_DIS_Nov-Dec + SP_TEMP & 225.201 & 7.720 & 0.010 \\
\hline 7 & YOY PS_DIS_Dec-Mar & 226.648 & 9.168 & 0.005 \\
\hline 8 & YOY SP_DIS_Sep-Oct & 234.632 & 17.151 & 0.000 \\
\hline 9 & YOY SP_DAYS $>100$ & 236.930 & 19.450 & 0.000 \\
\hline 10 & YOY SP_DIS_Nov-Dec+ SP_DAYS $>100$ & 223.891 & 6.410 & 0.019 \\
\hline 11 & YOY SP_DIS_Nov-Dec + PS_SSA & 217.481 & 0.000 & 0.473 \\
\hline 12 & "YOY SP_DIS_Nov-Dec + SP_DAYS $>100+$ PS_SSA & 220.073 & 2.592 & 0.129 \\
\hline 13 & "YOY SP_DAYS>100 + PS_SSA+ PS_RIV_HEIGHT & 234.039 & 16.559 & 0.000 \\
\hline 14 & YOY SP_DAYS $>100+$ PS_SSA & 231.597 & 14.116 & 0.000 \\
\hline 15 & YOY SP_DIS_Nov-Dec + SP_TEMP + PS_SSA & 218.437 & 0.957 & 0.293 \\
\hline 16 & "YOY River + PS_DIS_Dec-Mar & 227.185 & 9.704 & 0.003 \\
\hline 17 & YOY River + SP_DIS_Sep-Oct & 234.288 & 16.807 & 0.000 \\
\hline 18 & YOY River + SP_DAYS >100 & 240.477 & 22.997 & 0.000 \\
\hline 19 & YOY River + SP_DIS_Nov-Dec+ SP_DAYS $>100$ & 224.864 & 7.384 & 0.011 \\
\hline 20 & YOY River + SP_DIS_Nov-Dec + PS_SSA & 222.965 & 5.485 & 0.028 \\
\hline 21 & $\begin{array}{l}=\text { YOY River + SP_DIS_Nov-Dec + SP_DAYS }>100+ \\
\text { PS_SSA }\end{array}$ & 226.013 & 8.532 & 0.006 \\
\hline 22 & YOY $\sim$ River + SP_DAYS $>100+$ PS_SSA+ PS_RIV_HEIGHT & 242.138 & 24.657 & 0.000 \\
\hline 23 & YOY River + SP_DAYS $>100+$ PS_SSA & 238.835 & 21.354 & 0.000 \\
\hline 24 & YOY River + SP_DIS_Nov-Dec + SP_TEMP + PS_SSA & 225.560 & 8.079 & 0.007 \\
\hline
\end{tabular}

This article is protected by copyright. All rights reserved. 


\section{Figure captions}

Figure 1. Location of each of the five Macquarie perch populations used for the multipopulation analyses.

Figure 2. Mean daily discharge during November and December (solid line) and water temperature during October - December (dotted line) in (a) Yarra River; (b) King Parrot Creek; (c) Mitta Mitta River (Lake Dartmouth spawning tributary); (d) Hughes Creek and; (e) Sevens Creek, preceding annual fish surveys from 2007 - 2015.

Figure 3. Standardised annual counts (fish $1000^{-1}$ electrofishing seconds or net fleet) of young-of-year (YOY) Macquarie perch captured across the five sample rivers during annual surveys from 2007 - 2015. Standardised spawning stock abundance (x; no. fish estimated as $>4$ years of age per site) also included for reference. $n s=$ not sampled.

Figure 4. The predicted young-of-year (YOY) abundance $( \pm S E)$ of Macquarie perch in response to different levels of standardised mean daily discharge during November_December (SP_DIS_Nov-Dec where 1 = average discharge; $x$-axis) and; Spawning stock abundance (PS_SSA; left to right) under minimum (below average), average and maximum (above average); values based on actual data range. Note differing scales of $Y$ axis.

Figure 5. The mean annual predicted $( \pm S E)$ count of young-of-year (YOY) Macquarie perch for the five study rivers over the sampling period (2007 - 2015). Annual predictions based on site specific annual discharge during November-December (SP_DIS_Nov-Dec) and

This article is protected by copyright. All rights reserved. 
spawning stock abundance values (PS_SSA). For years lacking spawning stock abundance data, values were generated using the midpoint of the sample year prior to and following (generated over a three year period for Sevens); or the first year value for waterways missing prior data (King Parrot and Dartmouth).



This article is protected by copyright. All rights reserved. 
Supplementary material 1. Length-at-age growth curves for Macquarie perch displaying the relationship between total length $(\mathrm{mm})$ and estimated age (years) predicted by the Gompertz growth model for a lacustrine population (Black) and riverine populations (red) populations.

Length $\sim \mathrm{b} 1 * \exp (-\mathrm{b} 2 * \exp (b 3 *$ Age $))$

Where $\mathrm{b} 1=406.024 ; \mathrm{b} 2=2.00532 ; \mathrm{b} 3=-0.4244$ for lacustrine $\mathrm{and} ; \mathrm{b} 1=372.201 ; \mathrm{b} 2=$ $1.83718 ; b 3=-0.37764$ for riverine .

This article is protected by copyright. All rights reserved. 
Supplementary material 2. Linear regression model used to generate average daily water temperatures from October - December in the King Parrot Creek, Hughes Creek and Sevens Creek.

$\operatorname{Im}\left(\right.$ formula $=$ Temp $\sim$ Month ${ }^{*}$ day2 $+\min T+\log ($ Flow +1$)-1$, data $=$ Flow. data $)$

Where temp = average daily water temperature; Month = October, November or December; day 2 = day of month; $\operatorname{minT}=$ minimum daily air temperature and; Flow1 = standardised daily discharge.

Model parameter and summary output below:

\begin{tabular}{|l|l|l|l|l|}
\hline & Estimate & Std. Error & $\mathbf{t}$ value & $\operatorname{Pr}(\mathbf{>}|\mathbf{t}| \mathbf{)}$ \\
\hline MonthDecember & 19.780 & 0.574 & 34.461 & 0.000 \\
\hline MonthNovember & 14.517 & 0.508 & 28.604 & 0.000 \\
\hline MonthOctober & 10.880 & 0.516 & 21.08 & 0.000 \\
\hline day2 & -0.114 & 0.022 & -5.073 & 0.000 \\
\hline minT & 0.056 & 0.032 & 1.732 & 0.085 \\
\hline $\log$ Flow1 + 1) & -3.881 & 0.174 & -22.316 & 0.000 \\
\hline MonthNovember:day2 & 0.213 & 0.033 & 6.555 & 0.000 \\
\hline MonthOctober:day2 & 0.279 & 0.035 & 8.001 & 0.000 \\
\hline
\end{tabular}

Residual standard error: 1.559 on 169 degrees of freedom

Multiple R-squared: 0.9929; Adjusted R-squared: 0.9925

F-statistic: 2947 on 8 and 169 DF, p-value: $<2.2 \mathrm{e}-16$

This article is protected by copyright. All rights reserved. 
Supplementary material 3. Pairwise correlation coefficients (Pearson's) between each study system calculated for all flow and temperature variables used in the recruitment modelling. Specifically (a) average daily discharge November - December; (b) average daily discharge September - October; (c) average daily discharge Dec-March; (d) No. days flow change > 100\% Nov - Dec; (e) average daily water temperature Oct - Dec.

\begin{tabular}{|c|c|c|c|c|c|}
\hline \multicolumn{6}{|c|}{ (a) Nov-Dec Discharge } \\
\hline & Yarra & King Parrot & Dartmouth & Hughes & Sevens \\
\hline Yarra & 1 & & & & \\
\hline King Parrot & 0.940 & 1 & & & \\
\hline Dartmouth & 0.737 & 0.892 & 1 & & \\
\hline Hughes & 0.704 & 0.869 & 0.870 & 1 & \\
\hline Sevens & 0.777 & 0.917 & 0.899 & 0.993 & 1 \\
\hline \multicolumn{6}{|c|}{ (b) Sep-Oct Discharge } \\
\hline & Yarra & King Parrot & Dartmouth & Hughes & Sevens \\
\hline \multicolumn{6}{|c|}{\begin{tabular}{l|l} 
Yarra & 1 \\
\end{tabular}} \\
\hline King Parrot & 0.845 & 1 & & & \\
\hline Dartmouth & 0.777 & 0.837 & 1 & & \\
\hline Hughes & 0.571 & 0.856 & 0.793 & 1 & \\
\hline Sevens & 0.748 & 0.960 & 0.833 & 0.956 & 1 \\
\hline \multicolumn{6}{|c|}{ (c) Sum Discharge } \\
\hline & Yarra & King Parrot & Dartmouth & Hughes & Sevens \\
\hline Yarra & 1 & & & & \\
\hline King Parrot & 0.984 & 1 & & & \\
\hline Dartmouth & 0.909 & 0.887 & 1 & & \\
\hline Hughes & 0.976 & 0.994 & 0.870 & 1 & \\
\hline Sevens & 0.990 & 0.998 & 0.893 & 0.995 & 1 \\
\hline \multicolumn{3}{|c|}{ (e) Nov-Dec flow change days } & & & \\
\hline
\end{tabular}

This article is protected by copyright. All rights reserved. 


\begin{tabular}{|l|l|l|l|l|l|}
\hline & Yarra & King Parrot & Dartmouth & Hughes & Sevens \\
\hline Yarra & 1 & & & & \\
\hline King Parrot & 0.381 & 1 & & & \\
\hline Dartmouth & 0.261 & 0.563 & 1 & & \\
\hline Hughes & 0.302 & 0.887 & 0.569 & 1 & \\
\hline Sevens & 0.387 & 0.795 & 0.493 & 0.872 & 1 \\
\hline (f) Oct-Dec Temperature & \multicolumn{5}{|l|}{} \\
\hline & Yarra & King Parrot & Dartmouth & Hughes & Sevens \\
\hline Yarra & 1 & \multicolumn{5}{|l|}{} & & & \\
\hline King Parrot & -0.199 & 1 & & & \\
\hline Dartmouth & 0.190 & 0.747 & 1 & & \\
\hline Hughes & 0.334 & 0.707 & 0.851 & 1 & \\
\hline Sevens & 0.197 & 0.841 & 0.890 & 0.975 & 1 \\
\hline
\end{tabular}

This article is protected by copyright. All rights reserved. 
Supplementary material 4. Pairwise correlation coefficients (Pearson's) between standardised flow and temperature variables used in the recruitment modelling.

\begin{tabular}{|l|l|l|l|l|l|}
\hline & SO_flow & $\begin{array}{l}\text { SP_DIS_Nov } \\
- \text { Dec }\end{array}$ & $\begin{array}{l}\text { SP_TEM } \\
\text { P }\end{array}$ & $\begin{array}{l}\text { SP_DAYS }>10 \\
0\end{array}$ & PS_DIS_Dec-Mar \\
\hline SP_DIS_Sep-Oct & 1 & & & & \\
\hline SP_DIS_Nov-Dec & 0.823 & 1 & & & \\
\hline SP_TEMP & -0.369 & -0.399 & 1 & & \\
\hline SP_DAYS>100 & 0.034 & 0.143 & -0.160 & 1 & \\
\hline PS_DIS_Dec-Mar & 0.753 & 0.920 & -0.432 & 0.179 & 1 \\
\hline
\end{tabular}

This article is protected by copyright. All rights reserved. 


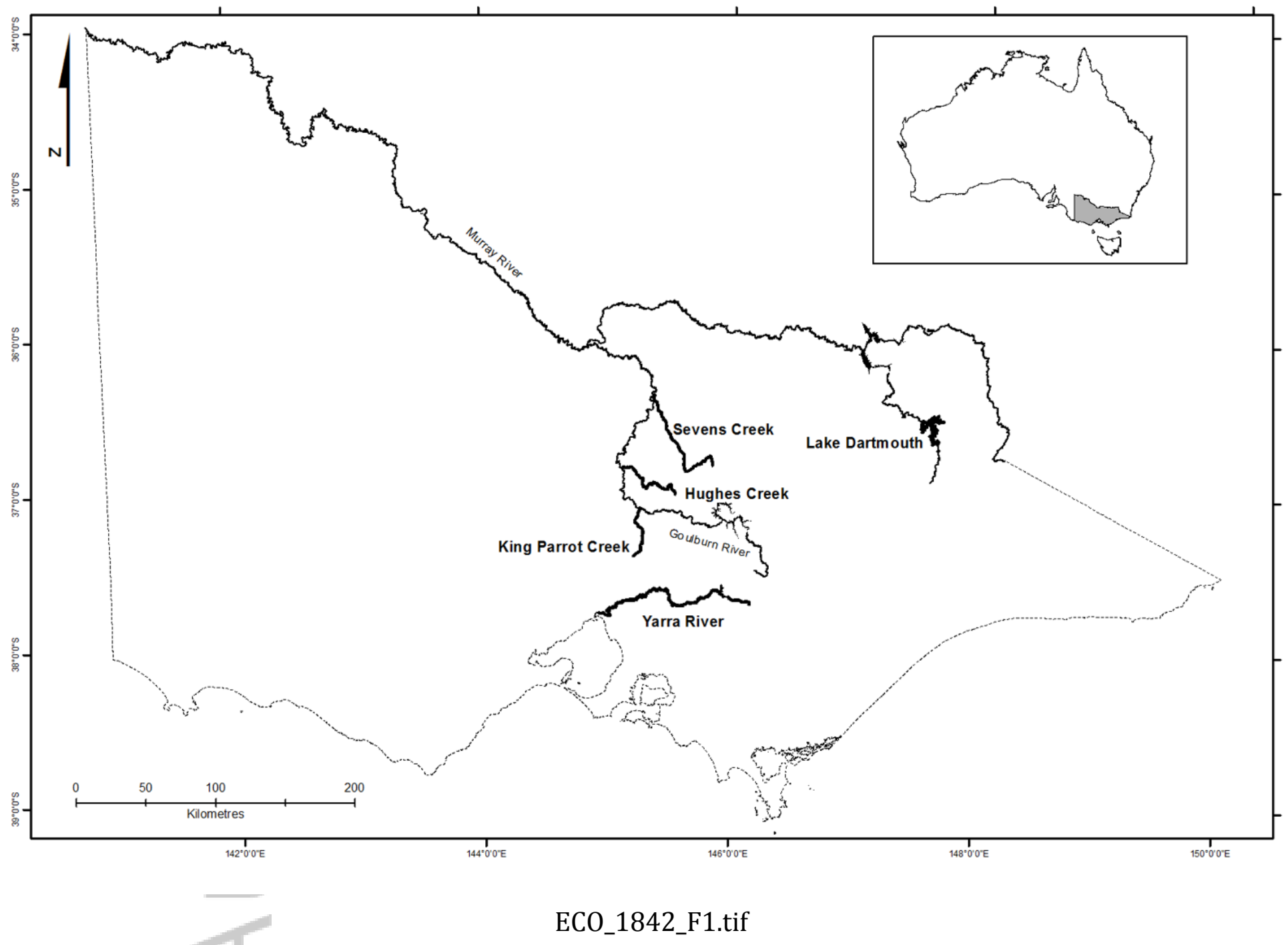

This article is protected by copyright. All rights reserved. 

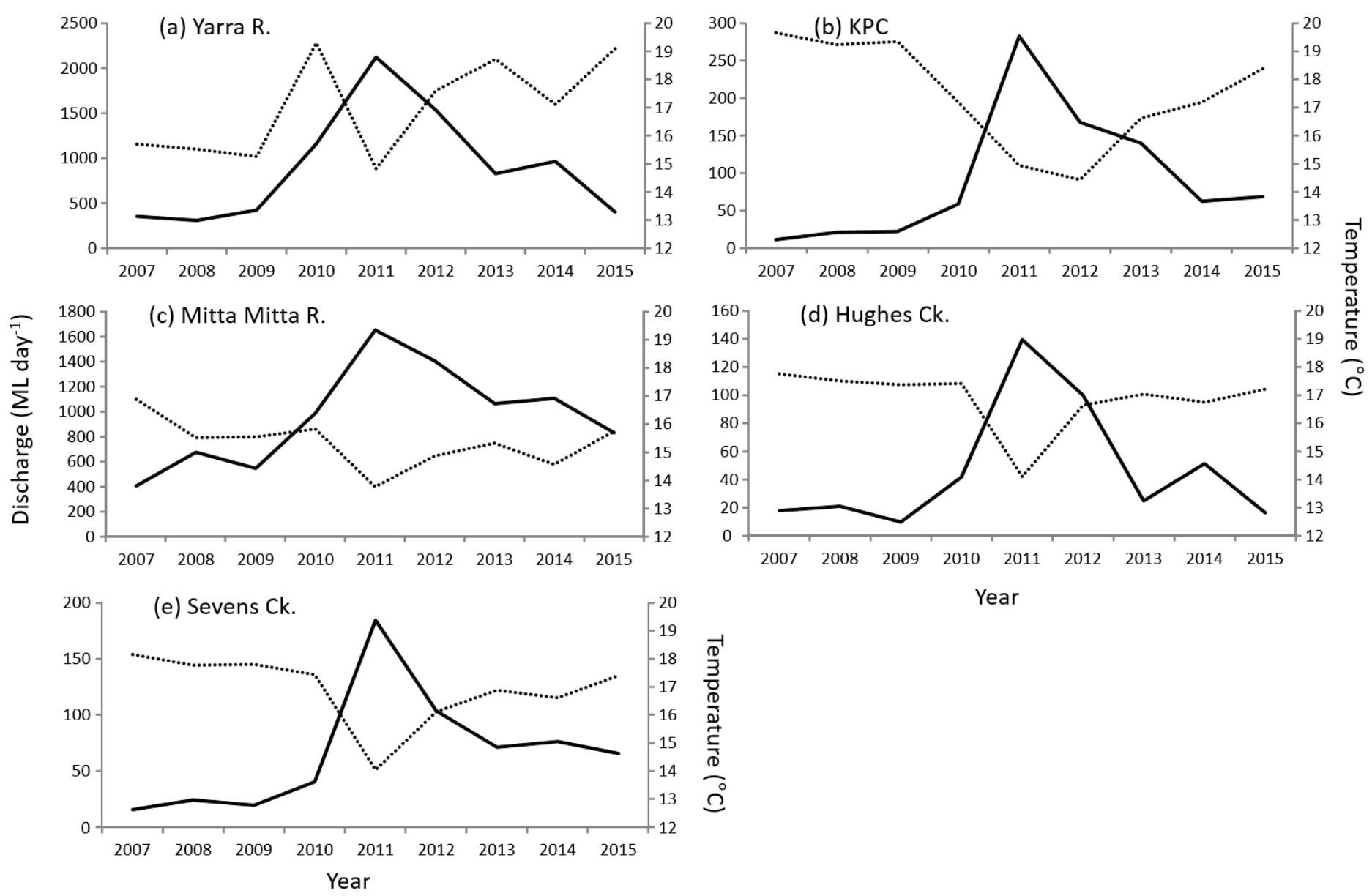

Year

ECO_1842_F2.tif

This article is protected by copyright. All rights reserved. 



ECO_1842_F3.tif 

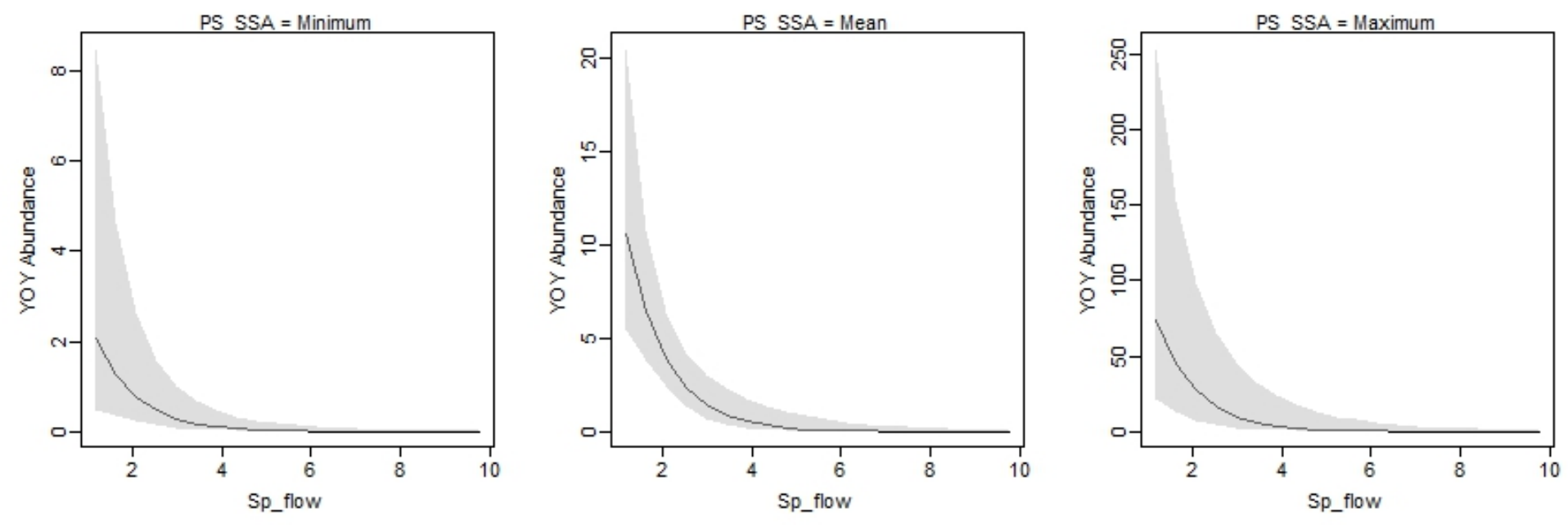

ECO_1842_F4.tif

This article is protected by copyright. All rights reserved. 

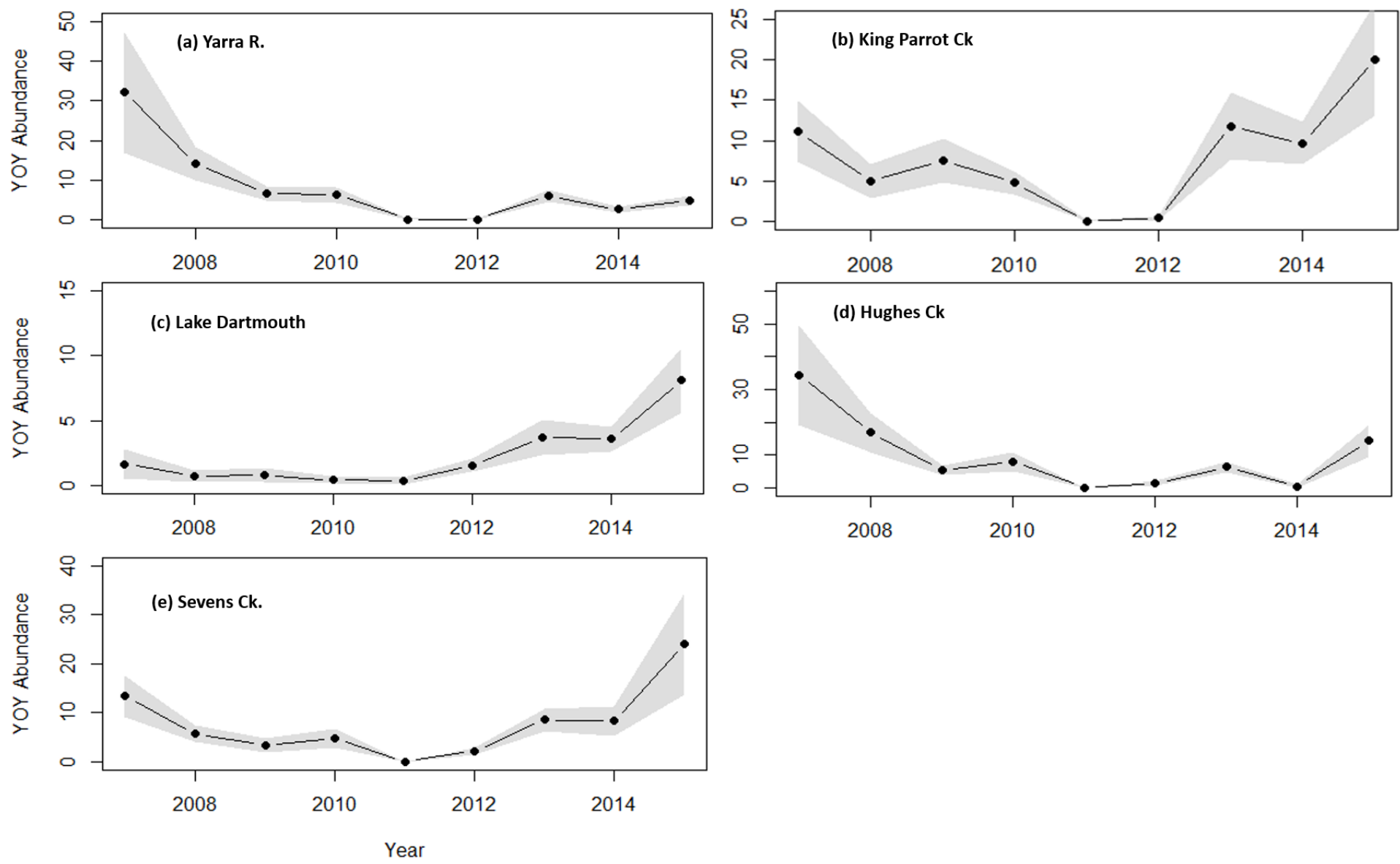

ECO_1842_F5.tif

This article is protected by copyright. All rights reserved. 


\section{University Library}

\section{- M M N E R VA A gateway to Melbourne's research publications}

Minerva Access is the Institutional Repository of The University of Melbourne

\section{Author/s:}

Tonkin, Z;Kearns, J;Lyon, J;Balcombe, SR;King, AJ;Bond, NR

Title:

Regional-scale extremes in river discharge and localised spawning stock abundance influence recruitment dynamics of a threatened freshwater fish

\section{Date:}

2017-09-01

\section{Citation:}

Tonkin, Z., Kearns, J., Lyon, J., Balcombe, S. R., King, A. J. \& Bond, N. R. (2017). Regionalscale extremes in river discharge and localised spawning stock abundance influence recruitment dynamics of a threatened freshwater fish. ECOHYDROLOGY, 10 (6), https:// doi.org/10.1002/eco.1842.

Persistent Link:

http://hdl.handle.net/11343/292914 